\title{
Effect of Accelerator on Compressive Strength Development of Class F Fly Ash Concrete
}

\author{
I Made Alit Karyawan Salain \\ Civil Engineering Department, Udayana University, Bali, Indonesia \\ imaksalain@unud.ac.id
}

\begin{abstract}
Effect of accelerator on compressive strength development of concrete made by utilizing a mixture of $90 \%$ type I Portland cement and $10 \%$ class F fly ash a hydraulic binder has been studied. Natural sand was used as fine aggregate and crushed stone as coarse aggregate. The grain distribution of natural sand and crushed stone were designed according to Indonesian Standard SNI 03-2834-2000 to meet the gradation zone 2 for fine aggregate and the granules with a maximum diameter of $20 \mathrm{~mm}$ for coarse aggregate. The mix proportion of concrete, by weight, was 1.0 binder: 2.0 fine aggregate: 3.0 coarse aggregate and water-binder ratio was 0.5 . The accelerator added to the concrete mixture was $2.5 \%, 5 \%, 7.5 \%$ and $10 \%$ by weight of mixing water. The control concrete was made without using the accelerator. Compressive strength test realized on cube specimens sizing of $150 \mathrm{~mm} \times 150 \mathrm{~mm} \times 150 \mathrm{~mm}$ at the age of $1,3,7,28,90$ days. The test results showed that the addition of accelerator in the concrete mixture accelerates the development of concrete compressive strength, especially at the age of 1 day, compared to control concrete. At this age, with the addition of $2.5 \%, 5 \%, 7.5 \%$ and $10 \%$ accelerator, the compressive strength of concrete increases by respectively $31.8 \%, 31.1 \%, 27.1 \%$ and $24.1 \%$. It was also noted that the addition of accelerator on the concrete mixture produces higher compressive strength at the age of 90 days compared to control concrete. It is finally found that the optimal use of accelerator to produce the greatest acceleration for the development of compressive strength in the early age and the highest compressive strength on the long period is $2.5 \%$. On that optimal use, the development of the compressive strength of concrete at 1 day is accelerated about $31.8 \%$ and the compressive strength of concrete at 90 days is about $\mathbf{1 2 . 5 \%}$ higher compared to control concrete.
\end{abstract}

Keyword - Accelerator, Compressive Strength, Type I Portland Cement, Class F Fly Ash

\section{INTRODUCTION}

Fly ash is one of residue produced from burning pulverized coal in electric power generating plants and composed of fine particles. This residue possess pozzolan character therefore commonly used in cement and concrete technology. Fly ash can be used as a raw material to produce Pozzolan Portland cement as well as Composite Portland cement or it can be added as an admixture during mixing the concrete.

The use of fly ash in cement and concrete technology has many benefits and it represents one of green technologies. It is noted that workability, strength, permeability and durability of concrete can be improved by using fly ash in the manufacture of concrete [1-3]. However the strength development of concrete with fly ash is generally slower in the early age than that of concrete without fly ash, although it produces a higher strength in long period [1-3]. This condition, to some extent, may limit the utilization of fly ash in concrete mixture, such as in prefabrication concrete industry. In this industry, sufficient early strength is needed to remove the formwork within 24 hours so that reducing the cycle time and resulting in cost-saving benefits [4].

Therefore, the efforts to accelerate the strength development of concrete with fly ash has to be studied so that the use of fly ash in concrete technology could be optimized. In this study, the use of accelerator in concrete made by using a mixture of type I Portland cement and class F fly ash as a hydraulic binder has been examined. The objective of this present study is to evaluate the performance of the accelerator in the development of the compressive strength of concrete.

\section{MATerials AND EXPERIMEnTAl Method}

Type I Portland cement (PCI) and class F fly ash (FFA) according to ASTM C-168 [5] have been used in this study. Table I gives the content of some oxides in PCI and FFA. Natural sand was used as fine aggregate and crushed stone as coarse aggregate. The grain distribution of natural sand and crushed stone were designed according to Indonesian Standard SNI 03-2834-2000 [6] to meet the gradation zone 2 for fine aggregate and the granules with a maximum diameter of $20 \mathrm{~mm}$ for coarse aggregate. The fineness modulus of this fine and coarse aggregates were 2.79 and 6.55 respectively. Table II shows some physical properties of the fine aggregate and the coarse aggregate. A commercial accelerator, in the form of a liquid, contains Calcium Chloride was used in this study. 
Table I. Oxides in PCI and FFA

\begin{tabular}{|c|c|c|}
\hline Oxides & PCI & FFA \\
\hline $\mathrm{Al}_{2} \mathrm{O}_{3}(\%)$ & 6.20 & 2.78 \\
\hline $\mathrm{CaO}(\%)$ & 61.46 & 1.82 \\
\hline $\mathrm{SiO}_{2}(\%)$ & 23.44 & 69.22 \\
\hline $\mathrm{Fe}_{2} \mathrm{O}_{3}(\%)$ & 0.54 & 0.49 \\
\hline
\end{tabular}

TABLE II. Physical Properties of Fine Aggregate and Coarse Aggregate

\begin{tabular}{|c|c|c|}
\hline Physical Properties & Fine Aggregate & Coarse Aggregate \\
\hline Unit weight $\left(\mathrm{g} / \mathrm{cm}^{3}\right)$ & 1.54 & 1.47 \\
\hline Specific gravity SSD & 2.62 & 2.68 \\
\hline Absorption (\%) & 3.84 & 0.60 \\
\hline Abrasion (\%) & - & 21.94 \\
\hline
\end{tabular}

The mixture proportion of concrete, by weight, was 1.0 binder: 2.0 fine aggregate: 3.0 coarse aggregate and the water-binder ratio was 0.5 . The binder was a mixture of $90 \%$ PCI and $10 \%$ FFA, by weight. Five mixtures were produced by varying the content of accelerator in the mixture: $0 \%, 2.5 \%, 5.0 \%, 7.5 \%$ and $10.0 \%$ by weight of mixing water. The mixture without accelerator (0\%) represents as control concrete. Each mixture was used to cast cube specimens sizing of $150 \mathrm{~mm}$ x $150 \mathrm{~mm}$ x $150 \mathrm{~mm}$. These cube specimens were kept in molds for 1 day and then demolded and cured with wet burlap until used for compressive strength test. All the specimens were prepared in accordance with Indonesian Standard SNI 2493:2011 [7]. Test of compressive strength was conducted at 1, 3, 7, 28 and 90 days, each using 3 cubical specimens. Figure 1 presents the preparation of the cubical specimens while Figure 2 shows the realization of compressive strength test.

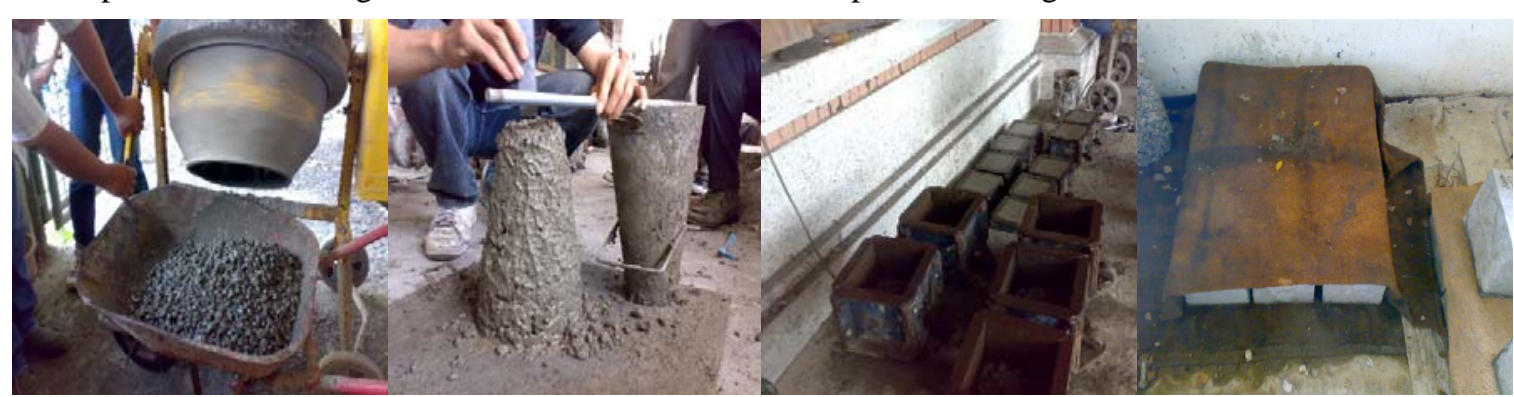

Fig. 1. Preparation of cubical specimens

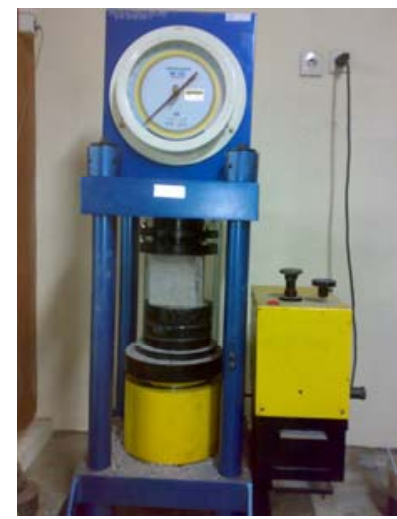

Fig. 2. Realization of compressive strength test

\section{RESUltS AND DisCUSSION}

\section{A. Results}

The results of the compressive strength test of concrete at the age of 1, 3, 7, 28 and 90 days for various percentage of accelerator are shown in Table 3 and Figure 3. From those table and figure, it is clear observed that the compressive strength development of concrete with accelerator is faster than that of control concrete, especially in the age of 1 day. 
TABLE III. Compressive Strength Test Results

\begin{tabular}{|c|c|c|c|c|c|}
\hline \multirow{2}{*}{$\begin{array}{c}\text { Accelerator } \\
\text { Content (\%) }\end{array}$} & \multicolumn{5}{|c|}{ Compressive Strength (MPa) } \\
\cline { 2 - 6 } & $\mathbf{1}$ day & 3 days & 7 days & 28 days & 90 days \\
\hline 0 & 12.6 & 24.6 & 31.7 & 40.7 & 45.0 \\
\hline 2.5 & 16.6 & 24.7 & 33.8 & 43.4 & 50.7 \\
\hline 5 & 16.5 & 25.6 & 34.2 & 43.3 & 48.7 \\
\hline 7.5 & 16.0 & 24.4 & 33.0 & 42.5 & 48.4 \\
\hline 10 & 15.6 & 24.2 & 31.3 & 41.3 & 47.2 \\
\hline
\end{tabular}

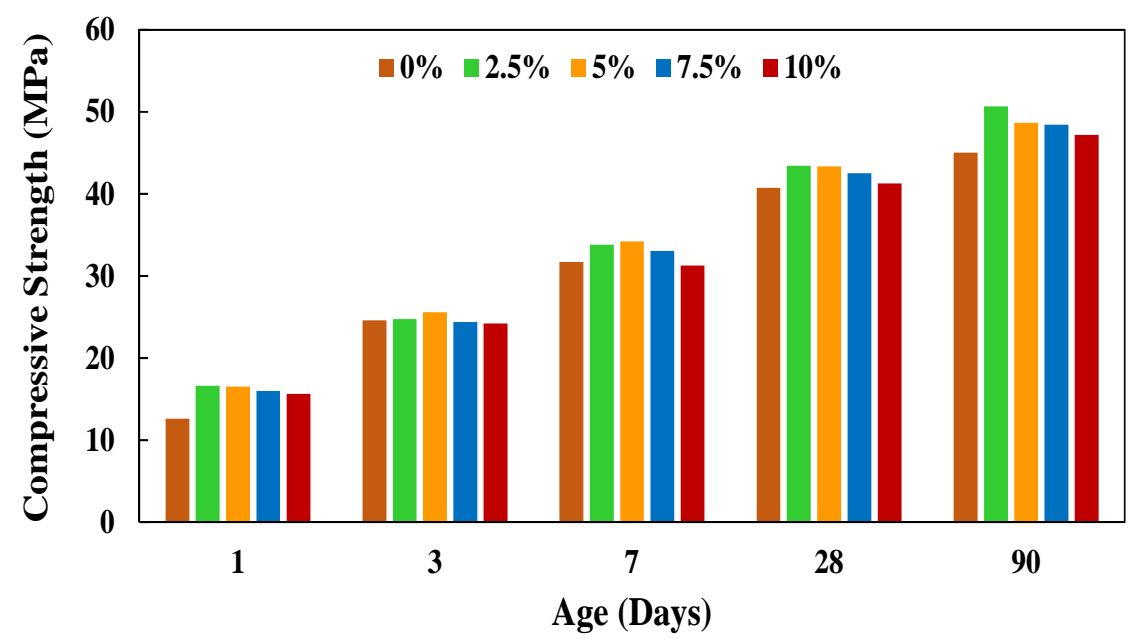

Fig. 3. Compressive Strength as a Function of Age and Accelerator Content in the Mixture

At the age of 1 day, with the addition of 2.5\%,5\%, 7.5\% and 10\% accelerator, the compressive strength of concrete increases significantly so that resulting compressive strength gain respectively 31.8\%, 31.1\%, $27.1 \%$ and $24.1 \%$ compared to the control concrete. These results comply with BS EN 934-2, 2009 [8], which requires that the concrete with the addition of accelerator should have compressive strength at least $20 \%$ higher than the concrete without accelerator, at the age of 1 day.

However, at the age of 3 days, it seems that the effect of accelerator is not too much visible so that the compressive strength gain is relatively low, i.e. varying from $3.9 \%-0.6 \%$. At the age of 7 and 28 days, the gain increases about $6.6 \%-1.3 \%$. And finally, at the age of 90 days, with the addition of $2.5 \%-10 \%$ accelerator, the gain reaches around $12.5 \%-4.8 \%$. From the test results, it is also clearly noted that the compressive strength gain is inversely proportional to the percentage of accelerator used: the more accelerator added to the mixture, the smaller the gain is.

Referring to the result of compressive strength test as shown in Table 3 and Figure 3, it can be seen that the optimal use of accelerator to accelerate the compressive strength development at early age and to give simultaneously the highest compressive strength of concrete in long period is $2.5 \%$.

\section{B. Discussion}

It is well known that in Portland cement hydration process, from its four main minerals (C3S, C2S, C3A and C4AF) only C3S and C2S play a major role in the development of strength of paste hydrate [1-3]. C3S contributes to the development of early strength while C2S contributes in the long period strength. The presence of accelerator containing calcium chlorides in the mixture could accelerate the dissolution of Portland cement and fly ash minerals [2]. This condition accelerates the hydration process. So that the development of strength in concrete with accelerator becomes faster compared to that of the concrete without accelerator.

With the accelerated hydration process of C3S and C2S on Portland cement producing C-S-H and $\mathrm{Ca}(\mathrm{OH})_{2}$, the pozzolanic reaction that occurred between alumina and silica reactive of fly ash and $\mathrm{Ca}(\mathrm{OH})_{2}$ is also faster to produce additional binder compound, C-A-H and C-S-H, which contribute to the increase of the compressive strength of concrete. This phenomenon is more evident at the age of 1 day compared to the next ages. This can be attributed to the availability of free water that is relatively more abundant in the early hydration which facilitates the ionization of mineral Portland cement and fly ash. With this condition, hydration process becomes faster and the hardening process as well as the development of concrete strength become faster too. 
The presence of accelerator also plays significant role in increasing the solubility of minerals in Portland cement and fly ash, such that the hydration process becomes more perfect. This can be seen from the fact that at the long period, 90 days, the compressive strength of concrete with accelerator is relatively higher, compared to that of the concrete without accelerator. The lower compressive strength of concrete with increasing the percentage of accelerator in concrete could be connected to the presence of water in accelerator. The more accelerator added, the amount of water in concrete increase, so that it decreases the compressive strength of concrete proportionally.

\section{CONCLUSION}

Based on the results of the test realized, the following conclusion is presented.

- The accelerator used in this study can effectively accelerates the development of compressive strength of concrete made by using blended binder of 90\% type I Portland cement and 10\% class F fly ash at early age and provides higher compressive strength in long period.

- The optimal use of accelerator to produce the greatest acceleration for the development of compressive strength in the early age and the highest compressive strength on the long period is $2.5 \%$.

- On that optimal use, the development of the compressive strength of concrete at 1 day is accelerated about $31.8 \%$ and the compressive strength of concrete at 90 days is about $12.5 \%$ higher compared to control concrete.

\section{ACKNOWLEDGMENT}

The author thanks to all the parties who have helped and supported the implementation of the study from the beginning till the publication of this paper.

\section{REFERENCES}

[1] F. M. Lea, The Chemistry of Cement and Concrete, Edward Arnold Ltd., London, 1970.

[2] P. K. Mehta, Concrete Structure Properties, and Materials, Englewood Cliffs, New Jersey, 1986.

[3] M. Neville and J. J. Brooks, Concrete Technology, Longman, Singapore, 1998.

[4] P. S. Song and S. Hwang, "Mechanical Properties of High-Strength Steel Fiber-Reinforced Concrete”, Construction and Building Materials, Vol. 18, No. 9, pp. 669-673, 2004.

[5] Specification for Fly Ash and Raw or Calcined Natural Pozzolan for Use as a Mineral Admixture in Portland Cement Concrete, ASTM C 618, 1985.

[6] Procedure for Making Normal Concrete Mixed Design, Indonesian National Standard SNI 03-2834-2000, 2000.

[7] Tata Cara Pembuatan dan Perawatan Benda Uji Beton di Laboratorium, Indonesian National Standard SNI 2493:2011 (in Indonesian), 2011.

[8] Concrete admixtures-Definitions, requirements, conformity, marking and labeling, BS EN 934 Part 2, 2009.

\section{AUTHOR PROFILE}

I Made Alit Karyawan Salain is a lecturer at Civil Engineering Department of Udayana University in Bali, Indonesia. He is a Civil Engineer from Bandung Institute of Technology in Bandung, Indonesia, DEA and DR in Civil Engineering from INSA de Lyon in France. His research focused on valorization of industrial wastes in the field of Civil Engineering. 